\title{
Preparation of Tuna Skin Byproduct Film Containing Pinus thunbergii Cone Extract
}

\author{
Jing-Gi Bak ${ }^{1,2, *}$, Jin Kim ${ }^{3, ;, * *}$ and Seung-Ho Ohk ${ }^{4, ;, * *}$ \\ ${ }^{1}$ Moneykey Co., Ltd. Gwangju 62399, Korea \\ ${ }^{2}$ Department of Biomedical Engineering, Chonnam National University, Gwangju 61186, Korea \\ ${ }^{3}$ Dental Healthcare \& Clinical Trial Center, College of Dentistry, Chosun University, Gwangju 61452, Korea \\ ${ }^{4}$ Department of Oral Microbiology, School of Dentistry, Chonnam National University, Gwangju 61186, Korea
}

Tuna skin byproduct extract (TSB) was used as a biocompatibility film base material, and its composite film with gellan gum (GG) was prepared. In addition, Pinus thunbergii cone extract (PTCE) was incorporated into the film to provide anti-oxidant and anti-bacteria activities. The tensile strength (TS) of the TSB/GG composite films increased with increasing GG content, whereas elongation at break (E) decreased. TSB/GG film at a ratio of 0.5:0.5 (w/w) showed the most desirable TS and E values. Based on scavenging free radical potentials and disc diffusion method results against growth of bacteria, antioxidant and anti-bacteria activities of films increased with increasing PTCE concentration. Accordingly, this study showed that TSB/GG could be used as a film material while the TSB/GG composite film containing PTCE can be utilized as functional packaging.

Key Words: Fish byproduct, Bio degradable films, Pinus thunbergii cone extract

\section{서 론}

환경에 대한 관심이 많아지면서 천연자원을 활용하는 소재 개발과 실생활에서 버려지는 플라스틱 소재의 폐기 물 등의 문제점을 해결하기 위해 플라스틱 포장재를 대 체할 수 있는 소재에 대한 연구가 많아지고 있다. 식품 가공 부산물 및 폐기물을 활용한 생분해성 필름 소재 개 발로 폐기물의 처리 비용 절감 및 그 활용 방안에 대한 관심이 증가되고 있는 추세이다(Yang et al., 2015; Yang and Song, 2016).

다양한 자원에서 얻어지는 부산물 중에 해양에서 활용
되는 부산물은 유효 성분을 추출하거나 동식물의 비료, 가축 사료로 일부 사용되고 있으나 활용도는 매우 미비하 여, 활용 방안 증가를 위해서는 더 많은 연구가 필요하다. 또한, 생분해성 필름에 사용되는 천연 소재의 대부분은 플라스틱 소재의 필름보다 낮은 물성을 가지고 있어 이 를 보완하기 위해 다양한 천연고분자를 혼합하여 필름을 제조하는데, 그 중에서도 키토산(chitosan), 한천(agar), 젤 라틴(gelatin), 젤란검(gellan gum) 등의 소재가 뛰어난 필름 형성능력을 갖추고 있다고 보고되었다(Vanin et al., 2005).

해양부산물 중 참치부산물(Tuna skin byproduct)의 경우 참치 통조림 가공 중 껍질이나 뼈 등과 같은 부산물이 다량 발생한다. 가공 중 발생하는 부산물에 양은 전체 원

Received: December 1, 2020 / Revised: December 17, 2020 / Accepted: December 18, 2020

*Ungraduate student, ${ }^{* *}$ Professor.

${ }^{\dagger}$ To whom all correspondence should be addressed.

${ }^{\dagger}$ Corresponding author: Jin Kim. Dental Healthcare \& Clinical Trial Center, College of Dentistry, Chosun University, Gwangju 61452, Korea.

Tel: +82-62-230-6883, Fax:+82-62-608-5407, e-mail: cream4251@chosun.ac.kr

$\dagger$ Corresponding author: Seung-Ho Ohk. Department of Oral Microbiology, School of Dentistry, Chonnam National University, Gwangju 61186, Korea. Tel: +82-62-530-4852, Fax:+82-62-530-4855, e-mail: shohk@chonnam.ac.kr

(C) The Korean Society for Biomedical Laboratory Sciences. All rights reserved.

(C) This is an Open Access article distributed under the terms of the Creative Commons Attribution Non-Commercial License (http://creativecommons.org/licenses/by-nc/3.0/) which permits unrestricted non-commercial use, distribution, and reproduction in any medium, provided the original work is properly cited. 
료의 3 분의 1 정도를 차지하고 일부만이 식품원료로 재 이용되어 대부분이 사료로 이용되거나 폐기물로 버려지고 있다. 부산물의 회분을 제외하고는 대부분 조지방(crude fat)과 단백질에 속하는 젤라틴(gelatin), 콜라겐(collagen)이 풍부하게 구성되어 있기에 친환경적인 생분해성 필름 또 는 포장재 소재로의 활용이 가능하다(Kim, 2005; Lee et al., 2010; Kim et al., 2019).

식품 포장재의 경우 저장, 유통 중 발생하는 미생물의 성장이나 오염, 식품의 산화를 감소시키기 위해 항균 및 항산화 물질이 포함된 기능성이 가미된 포장재의 개발이 이루어지고 있다. 대부분의 소비자는 오래 전부터 합성화 학소재의 식품첨가물의 안전성에 대해 일반적으로 기피 하는 경향이 대중화되어 있으면서 자연히 천연물 소재에 대한 욕구가 증가되고 있다. 소비자의 욕구를 충족시킬 수 있는 천연 보존제를 비롯하여 생리활성 및 품질 강화 제와 같은 광범위한 분야에서 실제 이용할 수 있는 연구 자료가 필요하다. 천연물 보존제로 가장 많이 사용되고 있는 자몽종자 추출물(grapefruit seed extract), 폴리라이신 (polylysine) 및 프로폴리스(propolis)의 경우 대부분이 수입 에 의존하고 있으며, 현 코로나19 사태로 인해 수입이 불 가피해져 가격 상승으로 인해 천연 보존제의 수급은 문 제점을 가지고 있다. 국내 자생하는 소나무의 열매(솔방 울)에서의 mono-, sesqui-, diterpenoids계 화합물의 항균, 항 산화 등의 활성이 보고되면서 소나무의 잎, 껍질, 열매 등의 polyphenol에 대한 연구는 바이오산업분야에 다양하 게 활용되고 있다(Yuki et al., 2020). 따라서 본 연구에서는 바닷가 주변에 자생하는 소나무속 종에 속하는 곰솔(해 송) 나무의 열매(Pinus thunbergii cone extract)를 채집하여 추출한 성분을 평가하고 참치부산물 추출물 조성에 천연 추출물을 첨가하여 복합필름을 제조하고, 항산화, 항균 능 력을 평가하여 식품 포장재 소재로서의 개발 가능성을 확인하였다.

\section{재료 및 방법}

\section{시약 및 재료}

참치부산물(Tuna skin byproduct, TSB)은 광주 양동시장 소재 수산 업체에서 제공받았다. 젤란검(Gellan gum, GG) 은 Sigma-Aldrich (St. Louis, MO, USA)에서 구입하여 사용 하였다. 곰솔열매(Pinus thunbergii cone extract, PTCE)는 완 도 명사십리 근처의 나무에서 채집하여 사용하였다. 이외 에 모든 시약은 정제 과정 없이 사용하였으며, 3 차 증류
수를 사용하였다.

\section{참치부산물 분말 제조}

참치부산물의 껍질과 뼈를 분리하고 흐르는 물에 세척 후, $60^{\circ} \mathrm{C}$ 에서 48 시간 건조 한 후 하루 정도 흐르는 물에 담궈 불순물을 제거하였다. 무게를 잰 뒤, 10 배량의 $0.1 \mathrm{~N}$ 아세트산(acetic acid)에 담궈 $8^{\circ} \mathrm{C}$ 냉장실에 12 시간 동안 담 가 놓았다. 용액에 팽윤된 TSB를 흐르는 물로 12 시간 동 안 중화시켰다. 중화시킨 $\mathrm{TSB}$ 에 5 배의 물을 첨가한 뒤 $80^{\circ} \mathrm{C}$ 에서 4 시간 중탕하였다. 중탕 후, 용액 내에 포함된 불순물 제거를 위해 거름망을 사용하여 여과를 진행하였 다. 망으로 여과한 용액을 다시 $80^{\circ} \mathrm{C}$ 에서 가열시켜 최종 적으로 손질한 초기 무게로 농축시켜 동결건조 후 얻은 분말을 실험에 사용하였다.

\section{곰솔열매 추출물 제조}

곰솔열매는 증류수로 세척하여 열 건조기에서 건조하 였다. 분쇄한 열매가루 $30 \mathrm{~g}$ 을 $70 \%$ 에탄올 $300 \mathrm{~mL}$ 에 침 지시켜 $100^{\circ} \mathrm{C}$ 열을 가하여 $6 \mathrm{~h}$ 동안 추출하였다. 추출이 완료된 후에는 회전 진공 농축 추출기를 이용하여 에탄 올을 증발시켜 동결건조 후 분말형태의 PTCE를 제조하 였다.

\section{곰솔열매 추출물 성분 분석}

성분 분석을 위해 GC-MS 장비(GC-2010; Shimadzu Co., Japan)를 활용하였다. 추출물을 $\mathrm{DMSO}$ 에 충분히 용해시 킨 후, 원심분리기를 이용하여 부유물을 제거하고 마이 크로 필터로 여과하여 시료를 준비하였다. 컬럼은 BD-5 $(60 \mathrm{~mm} \times 0.25 \mathrm{~mm} \times 0.25 \mathrm{~mm})$, 이동 가스(carrier gas)는 이동 비율(flow rate) $1 \mathrm{~mL} / \mathrm{min}$, 주입구(injection) 온도는 $250^{\circ} \mathrm{C}$, split ratio $10: 1$, 온도는 $50 \sim 300^{\circ} \mathrm{C} / 3^{\circ} \mathrm{C}$ 승온, injection volume 은 $1 \mu \mathrm{L}$ 조건으로 분석을 하였다.

\section{곰솔열매 추출물(PTEC) 함유 복합필름 제조}

복합필름을 제조하기 위해 예비실험을 통해 TSB 분말 과 $\mathrm{GG}$ 를 전체 $2 \%$ 농도로 고정하고 $1: 0,0.7: 0.3,0.5: 0.5$ $(\mathrm{w} / \mathrm{w})$ 비율로 $100 \mathrm{~mL}$ 증류수에 첨가하여 90 분간 $100^{\circ} \mathrm{C}$ 에 서 교반한 후, 호모게나이저(IKA, Ultra-Turrax T25, Staufan, Germany)를 이용하여 $1,500 \mathrm{rpm}$ 에서 5 분간 homogenization 하였다. 감압여과(Whatman No. 4, Maidstone, UK)한 PTEC 를 다양한 농도 $(0.5,1.0 \%)$ 에 첨가하여 30 분간 교반한 다음, 기포 제거를 위해 초음파 처리기(Ultrasonic bath, SD-350H, 
Table 1. Physical properties of tuna skin byproduct/gellan gum (TSB/GG) composite films

\begin{tabular}{ccc}
\hline \hline TSB:GG ratio & $\begin{array}{c}\text { Tensile strength } \\
(\mathrm{MPa})\end{array}$ & $\begin{array}{c}\text { Elongation at break } \\
(\%)\end{array}$ \\
\hline $1: 0$ & $1.31 \pm 0.07$ & $53.83 \pm 1.21$ \\
$0.7: 0.3$ & $15.3 \pm 0.69$ & $20.4 \pm 0.8$ \\
$0.5: 0.5$ & $22.63 \pm 1.41$ & $34.63 \pm 0.56$ \\
\hline
\end{tabular}

${ }^{1)}$ Values are mean $\pm \mathrm{SD}(\mathrm{n}=5)$

Seoul, Korea)를 이용하여 $60^{\circ} \mathrm{C}$ 에서 1시간 처리하였으며, 처리 후 실온에서 식힌 뒤 복합용액 $(25 \mathrm{~mL})$ 을 페트리디쉬 $(90 \mathrm{~mm})$ 에 균일하게 부어 $60^{\circ} \mathrm{C}$ 에서 18 시간 건조하여 건 조된 필름형태에 d-PBS를 처리하여 가교된 복합필름을 제조하였다.

\section{필름의 물성 측정}

필름의 물성을 측정하기 위해 ASTM Standard Method $\mathrm{D} 638 \mathrm{M}$ 방법에 따라 인장강도(tensile strength, TS)와 신장 률(elongation at break, E)을 평가하였다. 필름은 온도 $25^{\circ} \mathrm{C}$, 상대습도 $50 \%$ 에서 48시간 conditioning 한 후 Universal Testing Machine (TO-102D, TESTONE Co., Gyeonggi-do, Korea)을 사용하여 측정하였다.

\section{필름의 항산화 능력 측정}

필름의 항산화 능력 확인을 위해 추출물의 농도에 따라 제조한 복합필름을 생리식염수에 용출시켰다. 2,2-diphenyl1-picrylhydrazyl (DPPH), 2,2'-azino-bis(3-ethylbenzothiazoline6-sulphonic acid) (ABTS) 라디칼 소거능을 측정하였다(Ryu et al., 2017). DPPH 라디칼 소거능 측정을 위해 $0.8 \mathrm{mM}$ $\mathrm{DPPH}$ 용액을 메탄올로 제조 후, $\mathrm{DPPH}$ 용액 $1 \mathrm{~mL}$ 와 복합 필름 용액 $2 \mathrm{~mL}$ 를 혼합하여 암실에서 1 시간 반응시킨 뒤 $517 \mathrm{~nm}$ 에서 흡광도를 측정하였다. ABTS 라디칼 소거능 측정은 $7 \mathrm{mM}$ ABTS 용액을 제조 후 $2.45 \mathrm{mM}$ potassium persulfate의 혼합용액(2:1. v/v)을 3차수로 희석하여 $734 \mathrm{~nm}$ 에서 흡광도를 $0.8( \pm 0.01)$ 로 맞추어 사용하였다. ABTS 혼 합용액 $(2.85 \mathrm{~mL})$ 과 $0.15 \mathrm{~mL}$ 의 복합필름 용액을 혼합하여 암실에서 10 분간 반응시킨 뒤 측정하였다.

\section{균주 배양과 필름의 항균 능력 측정}

Escherichia coli (E. coil, KCTC 1115), Staphylococcus aureus (S. aureus, ATCC 6538)을 Nutrient broth (Difco Laboratories, Detroit, USA)에 접종하였다. $37^{\circ} \mathrm{C}, 24$ 시간 배양한 균 액을

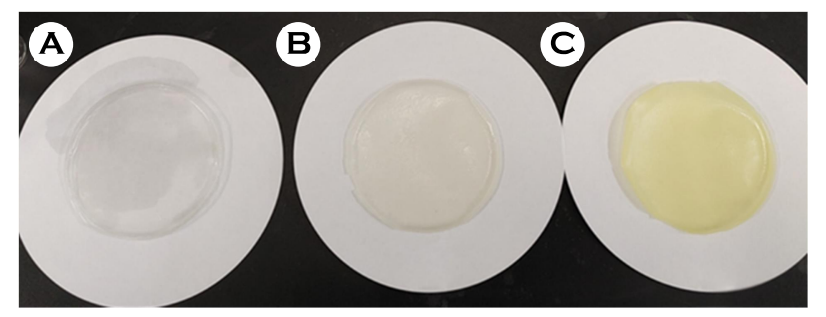

Fig. 1. Digital photoimages of tuna skin byproduct/gellan gum (TSB/GG) composite films containing of Pinus thunbergii cone extract (PTCE). (A); TSB/GG, (B); TSB/GG-PTCE (0.5\%), (C); TSB/GG-PTCE (1\%)

필름의 항균 능력 측정을 위한 디스크 확산법을 사용하 였다. 배양된 E. coil, S. aureus를 $\mathrm{NB}$ 액체배지에 $10^{7} \mathrm{CFU} /$ $\mathrm{mL}$ 로 희석한 균을 $\mathrm{NB}$ 고체배지에 $100 \mu \mathrm{L}$ 적하시켜 살균 된 glass spreader를 이용하여 도말하였다. 멸균된 paper disc (8 mm, Advantec, Tokyo, Japan)에 필름형성용액을 $50 \mu \mathrm{L}$ 씩 점적한 뒤 균이 도말된 배지에 부착시켜 $37^{\circ} \mathrm{C}$ 에서 24 시 간 배양 후 생성된 inhibition zone의 지름을 측정하였다.

\section{통계처리}

모든 실험 결과는 평균값(mean)과 표준편차(standard deviation, SD)로 표시하였다. 대조군과 실험군 사이의 통 계학적 유의성 검정은 Student's $t$-test로 비교하였으며 $P$ 가 0.05 이하인 것만 유의한 것으로 하였다.

\section{결 과}

\section{참치부산물/젤란검(TSB/GG)조성 복합필름의 물성}

참치부산물에 산 처리하여 얻은 분말(TSB)과 물성 확 보를 위해 혼합한 $\mathrm{GG}$ 의 복합필름의 물성을 관찰하였다. 복합필름에 표면형상은 Fig. 1에 나타냈다. 비율에 따른 $\mathrm{TSB} / \mathrm{GG}$ 필름의 인장강도를 측정하였을 때, $\mathrm{TSB}$ 의 비율 이 낮아짐에 따라 인장강도 값이 증가되는 것을 확인하 였다(Table 1). 이는 복합필름 제조 시 첨가되는 $\mathrm{GG}$ 의 농 도가 높아짐에 따라 필름의 물성이 향상되었다. 하지만, $\mathrm{GG}$ 의 비율이 상대적으로 높아지면 필름이 형성되지 않고 딱딱해지고 깨지기 쉬운(brittle) 물성이 되는 것을 확인하 였다. 본 연구 결과와 유사하게 Xanthan gum 필름에 $\mathrm{GG}$ 을 첨가하였을 때 그 비율이 증가함에 따라 TS가 증가하 고 $\mathrm{E}$ 가 감소하는 것은, 필름 주재료인 고분자 물질과 $\mathrm{GG}$ 간의 결합 증가에 의한 물성 변화로 기인한다(Zhang et al., 2020). 또한, 알로에 겔 조성에 $\mathrm{GG}$ 를 첨가함에 따라 $\mathrm{TS}$ 
가 증가하는 것이 확인되었다(Alvarado-González et al., 2012). 이러한 결과를 바탕으로 $\mathrm{TSB} / \mathrm{GG}$ 복합필름의 인장 강도 및 신장률은 TSB:GG 비율이 0.5:0.5 (w/w)일 때가 최적 조건이었으며, 이때 물성은 TS가 $22.63 \pm 1.41 \mathrm{MPa}$ 이 었고 $\mathrm{E}$ 는 $34.63 \pm 0.56 \%$ 였다.

\section{곰솔추출물(PTCE)의 성분 분석}

$70 \%$ 에탄올 곰솔열매 추출물 분석 결과 50 여개의 피 크를 확인하였다(Fig. 2). 주요 성분 위주의 화합물을 나열 하였다(Table 2). 해송추출물의 주요 성분은 kaura-type의 diterpen계 화합물이 $23.73 \%$ 이며, diterpen계 화합물의 대 부분은 진통작용, 진정작용, 항염증작용이 보고되고 있다
(Yen and Chen, 1995). 천연식물의 resin에서 주로 검출되는 phenanthrene carboxaldehyde 화합물은 $10.18 \%$ 로, 잣나무부 산물을 에탄올로 추출한 경우 $9.23 \%$ 로 비슷한 함유량이 관찰되었다. 솔방울의 경우 대부분이 diterpen계 화합물이 가장 많이 함유되어 있었다. 특히, 송진의 주요 성분인 abietic acid의 함유량은 $12.66 \%$ 로 나무의 종류에 따라 함 유량이 다르며 항균성 항생 물질로 알려져 있다(Kim et al., 2008; Yuki et al., 2020).

\section{곰솔추출물(PTCE) 함유 복합필름 물성}

$\mathrm{TSB} / \mathrm{GG}$ 복합필름에 항균 및 항산화 능력을 부여하기 위해 다양한 농도의 $\operatorname{PTCE}(0,0.5,1.0 \%)$ 를 필름형성용액

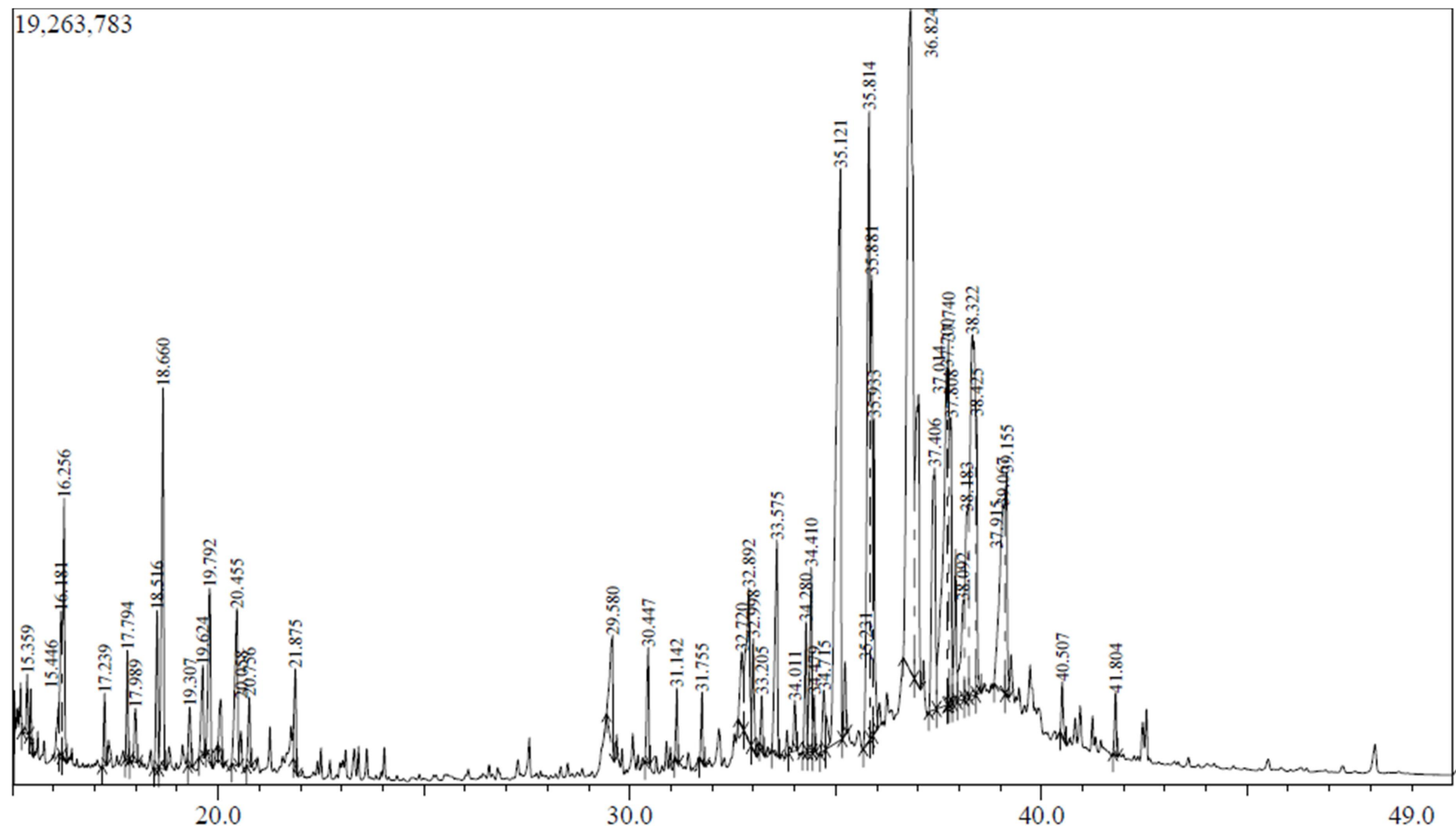

Fig. 2. Gas chromatography-mass spectrometry (GC-MS) analysis of Pinus thunbergii cone extract (PTCE).

Table 2. Chemical compositions of Pinus thunbergii cone extract (PTCE) by Gas chromatography-mass spectrometry (GC-MS) analysis

\begin{tabular}{cllcc}
\hline \hline Peak & \multicolumn{1}{c}{ Compound name } & Formular & Real.Time (min) & Area (\%) \\
\hline 1 & Kaura-5,16-dien-18(or 19)-ol & $\mathrm{C}_{20} \mathrm{H}_{30} \mathrm{O}$ & $36.82,38.32,38.13$ & 23.73 \\
2 & Phenanthrene carboxaldehyde, & $\mathrm{C}_{15} \mathrm{H}_{10} \mathrm{O}$ & 35.12 & 10.18 \\
3 & Cholesteryl bromide & $\mathrm{C}_{27} \mathrm{H}_{45} \mathrm{Br}$ & 35.81 & 6.40 \\
4 & Abietic acid & $\mathrm{C}_{20} \mathrm{H}_{30} \mathrm{O} \mathrm{O}_{2}$ & $37.7,39.06$ & 12.66 \\
5 & Androstan-17-one & $\mathrm{C}_{21} \mathrm{H}_{34} \mathrm{O}_{2}$ & 37.01 & 4.01 \\
6 & Vitamin A & $\mathrm{C}_{20} \mathrm{H}_{30} \mathrm{O}$ & 35.88 & 3.28 \\
\hline
\end{tabular}


Table 3. Physical properties of tuna skin byproduct/gellan gum (TSB/GG) composite films containing various amounts of Pinus thunbergii cone extract (PTCE)

\begin{tabular}{ccc}
\hline \hline $\begin{array}{c}\text { Pinus thunbergii } \\
\text { cone extract (\%) }\end{array}$ & $\begin{array}{c}\text { Tensile strength } \\
\text { (MPa) }\end{array}$ & $\begin{array}{c}\text { Elongation at break } \\
(\%)\end{array}$ \\
\hline 0.5 & $20.8 \pm 1.14$ & $40.8 \pm 0.91$ \\
1 & $16.34 \pm 0.77$ & $50.13 \pm 1.59$ \\
1.5 & $10.95 \pm 0.5$ & $56.8 \pm 1.21$ \\
\hline
\end{tabular}

1) Values are mean $\pm \mathrm{SD}(\mathrm{n}=5)$
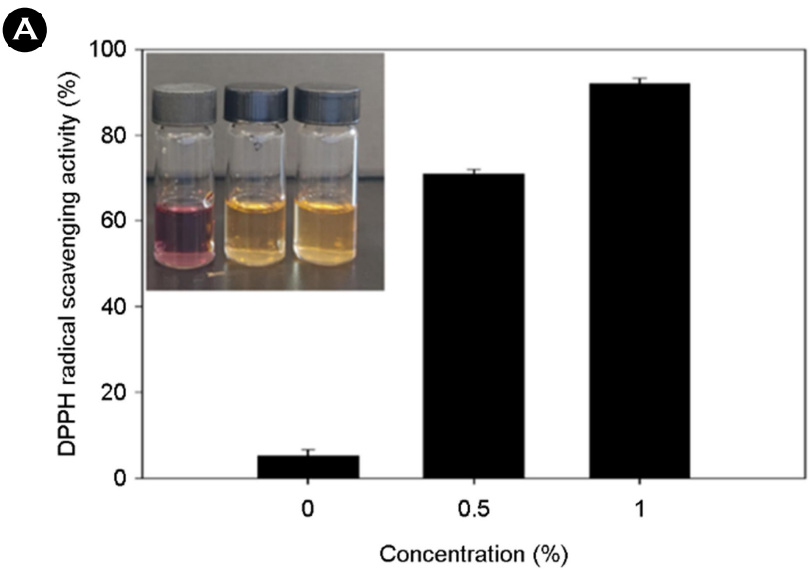

Table 4. Antioxidant activities of tuna skin byproduct/gellan gum (TSB/GG) composite films containing various amounts of Pinus thunbergii cone extract (PTCE)

\begin{tabular}{ccc}
\hline \hline $\begin{array}{c}\text { Pinus thunbergii } \\
\text { cone extract (\%) }\end{array}$ & $\begin{array}{c}\text { DPPH radical } \\
\text { scavenging (\%) }\end{array}$ & $\begin{array}{c}\text { ABTS radical } \\
\text { scavenging (\%) }\end{array}$ \\
\hline 0 & $5.18 \pm 1.52$ & $9.4 \pm 1.12$ \\
0.5 & $71.1 \pm 1.04$ & $39.06 \pm 0.86$ \\
1 & $92.07 \pm 1.32$ & $73.35 \pm 3.67$ \\
\hline
\end{tabular}

1) Values are mean $\pm \mathrm{SD}(\mathrm{n}=5)$

B

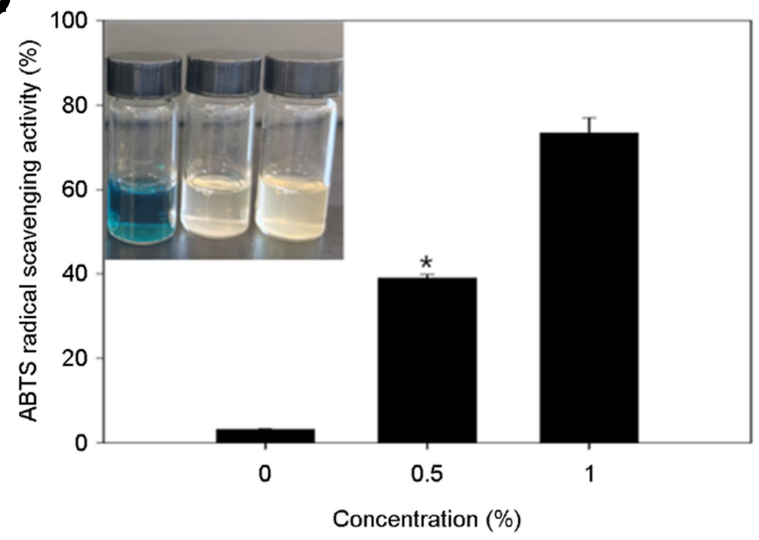

Fig. 3. Antioxidant activity of tuna skin byproduct/gellan gum (TSB/GG) composite films containing of Pinus thunbergii cone extract (PTCE). (A) DPPH radical, (B) ABTS radical assay.

(TSB/GG)에 첨가하여 필름을 제조하였다(Table 3). PTCE 농도가 증가함에 따라 $\mathrm{PTCE}$ 를 첨가하지 않은 대조군 에 비해 $\mathrm{TS}$ 가 최대 $11.68 \mathrm{MPa}$ 까지 감소하고 $\mathrm{E}$ 가 최대 $22.17 \%$ 까지 증가하였다. 이러한 결과는 PTCE 첨가로 필 름 내 고분자 물질인 $\mathrm{TSB} / \mathrm{GG}$ 의 분자 간 결합 감소에 의 한 것이라고 판단된다.

본 연구 결과와 유사하게 한천(agar) 조성 필름에 천연 방부제 소재인 자몽종자 추출물을 첨가한 결과 추출물의 농도가 증가함에 따라 $\mathrm{TS}$ 가 감소하고 $\mathrm{E}$ 가 증가하였는데, 이러한 결과는 필름 내 $\mathrm{agar}$ 와 같은 고분자 물질 간의 결 합이 감소함에 따른 결과라고 보고하였다(Kanmani and Rhim, 2014).

\section{곰솔추출물(PTCE) 함유 복합필름의 항산화 및 항균 능력}

다양한 농도의 $\mathrm{PTCE}$ 를 첨가한 $\mathrm{TSB} / \mathrm{GG}$ 복합필름의 항 산화 능력을 확인하기 위해 DPPH, ABTS 라디칼 소거능 을 측정하였다(Fig. 3, Table 4). 비교적 안정한 free radical 로 $\mathrm{DPPH}$ 와 $\mathrm{ABTS}$ 는 항산화 활성 측정에 많이 사용되고
있는데, hydrophilic 또는 lipophilic 물질 모두 측정된다. $\mathrm{DPPH}$ 는 음이온 라디칼을 $\mathrm{ABTS}$ 는 양이온 라디칼을 생성 하는 차이가 있다. 이 두 가지 방법은 기질과 반응 물질의 결합 정도가 서로 달라 라디컬 소거능 결과가 상이할 수 도 있다고 알려져 있다(Lee et al., 2012).

각각의 라디칼 소거능 결과를 통해 항산화능이 확인되 었다. 이러한 결과는 곰솔열매 추출물 내 다양한 polyphenol에 의한 것으로 판단된다. 또한 PTCE 첨가량이 증 가함에 따라 라디칼 소거능이 비례하게 증가하였는데, 특히, $\mathrm{DPPH}$ 라디컬 소거능에서는 $0.5 \%$ 의 농도에서 $\mathrm{IC}_{50}$ (inhibitory concentrations 50)에 가까운 값이 관찰되었으며 이러한 결과는 솔방울 추출물의 농도별 DPPH 라디칼 소 거능 결과와 유사하였다(Lee et al., 2016).

또한, 디스크 확산법을 통해 E. coli, S. aureus의 생육 억 제능을 측정하였다(Fig. 4). E. coli, S. aureus는 광범위한 생 육 온도에서 성장하며, 식품에 관여하는 미생물로 항균 능력 측정 대상 균으로 선정하였다.

PTCE 농도가 $0,0.5,1.0 \%$ 로 증가함에 따라 생육저해환 
A

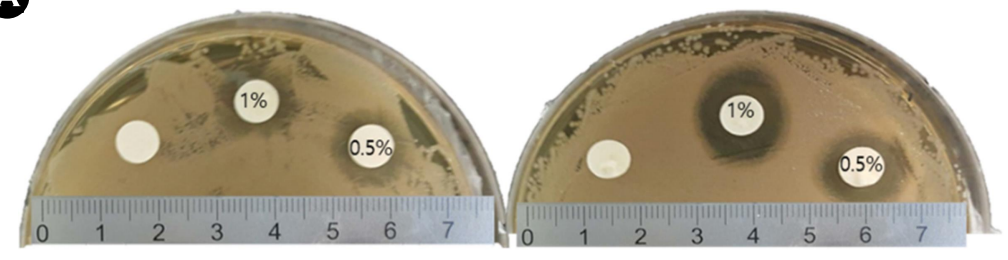

B

\begin{tabular}{ccc}
\hline \multirow{2}{*}{$\begin{array}{c}\text { Pinus thunbergii } \\
\text { cone extract (\%) }\end{array}$} & Escherichia coli & \multicolumn{2}{c}{ Staphylococcus aureus } \\
\cline { 2 - 3 } & \multicolumn{3}{c}{ Inhibition zone (mm) } \\
\hline 0 & - & - \\
\hline 0.5 & $12 \pm 1.2$ & $14 \pm 0.8$ \\
\hline 1 & $14 \pm 0.12$ & $18 \pm 1.2$ \\
\hline
\end{tabular}

Fig. 4. Antimicrobial activity of tuna skin byproduct/gellan gum (TSB/GG) composite films containing various amounts of Pinus thunbergii cone extract (PTCE) against Escherichia coli and Staphylococcus aureus by disc diffusion test. (A) The inhibition zone of PETC against Escherichia coli and Staphylococcus aureus. (B) Average diameter (mm) of the inhibition zones. Data are expressed as mean \pm standard error of the mean. (inhibition zone)이 농도 의존적으로 증가하여 E. coli, S. aureus 의 생육을 확연히 저해하는 것을 확인할 수 있었다. 특히, $\mathrm{TSB} / \mathrm{GG}$ 복합필름은 높은 온도 $\left(100^{\circ} \mathrm{C}\right.$ 이상)에서 녹 을 수 있는 특성이 있어 식품 포장재로 활용 가능한 소 재나 냉장 온도에서 유통되는 가공식품의 저장성 증대를 위한 기능성 포장 소재 및 약물의 담체로 활용 가능한 코 팅제형으로 활용이 가능할 것으로 판단된다.

\section{고 찰}

환경오염이나 폐기물에 대한 문제점을 해결하기 위해 플라스틱 포장재를 대체할 수 있는 소재에 대한 연구가 많아지고 있다. 해양부산물로부터 해양단백질 등 유효 성 분 추출 및 비료, 가축 사료로 일부 사용되고 있다. 부산 물의 활용 방안 증가를 위해서 많은 연구가 필요하다. 천 연고분자에 속하는 옥수수단백질(corn zein), 전분(starch), polylacticacid 등 소재로 제조된 포장재는 합성고분자 조 성의 포장재보다 물성이 낮으며 특히, 수분에 취약하며, 강도가 약한 문제점이 보고되고 있다(You et al., 2014). 특 히, 식품 포장재로 활용하기 위해 젤람검을 적용하여 물 성을 확보한 필름을 제조하였다. 또한, 천연고분자 조성 의 필름에 천연추출물 성분의 항산화 및 항균작용을 가 지는 Pinus thunbergii cone extract 성분을 첨가하여 기능성 필름을 제조하였다.

참치부산물에서 추출되는 해양단백질과 젤란검의 최적 비를 선정하여 제조한 복합필름에 곰솔열매 추출물을 함 유시켜 항산화 및 항균성을 첨가하였다. 곰솔열매의 성분
으로 주요 성분은 kaura-type의 diterpen계 화합물이 $23.73 \%$ 이며, diterpen계 화합물의 대부분은 진통작용, 진정작용, 항염증작용이 보고되고 있다(Yen and Chen, 1995). 천연식 물의 resin에서 주로 검출되는 phenanthrene carboxaldehyde 화합물은 $10.18 \%$, 송진의 주요 성분인 abietic acid의 함유 량은 $12.66 \%$ 로 항산화 및 항균작용에 관여하는 화합물이 확인되었다.

천연 항균 물질을 포함한 가식성 필름은 구강내 항균 작용을 위한 가식성 필름으로 개발되었다(Kim et al., 2009). 기존의 천연고분자 조성 포장재의 경우 셀룰로우즈, 키 틴, 전분 등 천연에서 쉽게 구할 수 있는 다양한 다당류 (polysaccharides)를 주로 말하며, 양모, 견사 등의 동물성 단백질이나 poly-hydroxyalkanoates 등의 폴리에스테르계도 성분이 사용된다(Scaffaro et al., 2019). 물성을 보완하기 위 한 연구가 진행되고 있다(González and Alvarez Igarzabal, 2013; Kurek et al., 2014). 카라긴난 필름의 경우 $0.1 \%$ 칼륨 염이 첨가되었을 때 인장강도가 $45 \mathrm{MPa}$ 였으며, 가소제와 칼륨염의 첨가에 따른 필름의 기계적 물성이 향상된 것을 확인하였다(Park et al., 1995).

본 연구에서 개발한 해양부산물 추출물(TSB)과 젤란검 (GG)의 비율이 1:1 (w/w)일 때 TS는 $22.63 \pm 1.41 \mathrm{MPa}$ 로 연 실률은 $34.63 \pm 0.56 \%$ 였다. TSB의 비율이 낮아짐에 따라 인장강도 값이 증가되는 것을 확인하였다. 이는 복합필름 제조 시 첨가되는 $\mathrm{GG}$ 의 농도가 높아짐에 따라 필름의 물 성이 향상되었다. 옥수수 전분을 제조하는 공정의 부산물 로 옥피(corn fiber)에 가소제와 가교제 ferulic acid, tannic acid, cinnamaldehyde를 첨가하여 물성을 확보하고, 천연 
물질은 녹차추출물을 첨가하여 항산화능, 항균성을 증가 시켜 식품 포장재로 활용하였다. 옥피 조성의 필름에 녹 차추출물의 함유량이 증가됨에 따라 TS가 낮아지는 연구 결과는 본 연구와 비슷한 경향을 나타냈다. 옥피단백질 과 결합하지 않은 녹차추출물의 폴리페놀 수산기 간 결 합에 의한 것이라고 판단하였으며(Bandyopadhyay et al., 2012), starch-chitosan film에 가교제로 ferulic acid를 첨가 시 $75 \mathrm{mg}$ 까지 $\mathrm{TS}$ 가 증가하였다가 $100 \mathrm{mg}$ 첨가한 경우 $\mathrm{TS}$ 가 감소하는 결과를 가졌다고 보고한 바 있다(Mathew and Abraham, 2008). 천연추출물 Pinus thunbergii cone extract을 함유시킨 필름의 항산화능은 추출물이 $0.5 \%$ 첨가했을 때 $\mathrm{IC}_{50}$ 에 가까운 값이 확인되었다. 특히, $1 \%$ 가 첨가되었을 때 $90 \%$ 가 넘는 항산화력을 확인하였다. 또한, E. coli와 $S$. aureus 항균력은 농도의존적으로 향상된 것을 확인하였 다. 녹차추출물이 함유된 옥피단백질 조성 필름에서도 이 와 유사한 결과를 확인하였으며, 녹차추출물의 함유량이 $1.0 \%$ 를 첨가하였을 때, 항산화 및 항균력이 더 효과적인 것을 확인하였다(Yang et al., 2015). 따라서, 본 연구 결과 항산화, 항균력 활성이 첨가된 참치부산물 조성의 복합필 름은 다양한 산업군에 활용 가능할 것으로 판단되며, 환 경보호와 생분해가 가능한 소재로 활용 가치가 높을 것으 로 기대된다.

\section{ACKNOWLEDGEMENT}

This study was financially supported by Chonnam National University (Grant number: (2018-3392).

\section{CONFLICT OF INTEREST}

The authors declare that they have no conflict of interest.

\section{REFERENCES}

Alvarado-González JS, Chanona-Pérez JJ, Welti-Chanes JS, Calderón-Domínguez G, Arzate-Vázquez I, Pacheco-Alcalá SU, Garibay-Febles V, Gutiérrez-López GF. Optical, microstructural, functional and nanomechanical properties of Aloe vera gel/gellan gum edible films. Revista Mexicana de Ingenieria Quimica. 2012. 11: 193-202.

Bandyopadhyay P, Ghosh AK, Ghosh C. Recent developments on polyphenol-protein interactions: effects on tea and coffee taste, antioxidant properties and the digestive system. Food Function. 2012. 3: 529-605.

González A, Alvarez Igarzabal CI. Soy protein-Poly (lactic acid) bilayer films as biodegradable material for active food packaging. Food Hydrocolloids. 2013. 33: 289-296.

Kanmani P, Rhim JW. Antimicrobial and physicalmechanical properties of agar-based films incorporated with grapefruit seed extract. Carbohydrate Polymers. 2014. 102: 708-716.

Kim CH, Lee SY, Pak JI. The Extraction of Essential Oil from Byproduct of pine nut cone and its antibacterial activity. Annals of Animal Resource Sciences. 2008. 19: 63-70.

Kim J, Im TJ, Kim SG, Lee KY, Development of fish byproduct extract based absorbable soft tissue bioadhesive. Polymer (Korea). 2019. 43: 372-378.

Kim KM, Hwang KT, You SG, Lee US, Jung KH, Moon SK, Choi WS. Antimicrobial effect of edible pullulan film containing natural antimicrobial material on cariogenic bacteria. Journal of the Korean Society of Food Science and Nutrition. 2009. 38: 1466-1470.

Kim YJ. Influence of dietary sea urchin shell powder on physicochemical properties of chicken meat. Korean Journal of Poultry Science. 2005. 32: 55-60.

Kurek M, Galus S, Debeaufort F. Surface, mechanical and barrier properties of bio-based composite films based on chitosan and whey protein. Food Packaging and Shelf Life. 2014. 1: 56-67.

Lee AR, Roh SS, Lee ES, Min YH. Anti-oxidant and antimelanogenic activity of the methanol extract of pine cone. Asian Journal of Beauty and Cosmetology. 2016. 14: 301-308

Lee S, You Y, Kim K, Park J, Jeong C, Jhon DY, Jun W. Antioxidant activities of native Gwangyang Rubus coreanus Muq. Journal of the Korean Society of Food Science and Nutrition. 2012. 41: 327-332.

Lee SJ, Ha WH, Choi HJ, Cho SY, Choi JW. Hepatic detoxification and antioxidant activity in sea-urchin roe and ethanol extract of roe. Korean Journal of Fisheries and Aquatic Sciences. 2010. 43: 428-436.

Mathew S, Abraham TE. Characterisation of ferulic acid incorporated starch-chitosan blend films. Food Hydrocolloid. 2008 22: 826-835.

Park JH, Rhim JW, Jung ST, Kang SG, Hwang KT, Park YK Mechanical properties of carrageenan-based biopolymer films. Korea Society of Packaging Science \& Technology. 1995. 1: 38-50.

Ryu MS, Yang HJ, Kim JW, Jeong SJ, Jeong SY, Eom JS, Jeong DY. Potential probiotics activity of Bacillus spp. from traditional soybean pastes and fermentation characteristics of Cheonggukjang. Korean Journal of Food Preservation. 2017. 24: $1168-1179$ 
Scaffaro R, Maio A, Sutera F, Gulino EF, Morreale M. Degradation and recycling of films based on biodegradable polymers: a short review. Polymers. 2019. 11: 651-671.

Vanin FM, Sobral PJA, Menegalli FC, Carvalho RA, Habitante AMQB. Effects of plasticizers and their concentrations on thermal and functional properties of gelatin based films. Food Hydrocolloids. 2005. 19: 899-907.

Yang HJ, Song KB, Preparation of sea urchin skeleton film containing Robinia pseudoacacia flower extract. Journal of the Korean Society of Food Science and Nutrition. 2016. 45: 778 -781 .

Yang HJ, Lee JH, Lee JH, Song KB. Characterization of a corn fiber protein film containing green tea extract. Journal of Applied Biological Chemistry. 2015. 58: 145-151.

Yen GC, Chen HY. Antioxidant activity of various tea extracts in relation to their antimutagenicity. Journal of Agricultural and Food Chemistry. 1995. 43: 27-32.

You YS, Kim MK, Park MJ, Choi SW. Development of oxo- biodegradable bio-plastics film using agricultural by-product such as corn husk, soybean husk, rice husk and wheat husk Clean Technology. 2014. 20: 205-211.

Yuki TI, Yamashiro K, Mineshiba F, Hirai K, Omori K, Yamamoto T, Takashiba S. Antimicrobial and antibiofilm effects of abietic acid on cariogenic Streptococcus mutans. Journal of Odontology. 2020. 108: 57-65.

Zhang N, Li X, Ye J, Yang Y, Huang Y, Zhang X, Xiao M, Effect of gellan gum and xanthan gum synergistic interactions and plasticizers on physical properties of plant-based enteric polymer films. Polymers. 2020. 12: 121-127.

https://doi.org/10.15616/BSL.2020.26.4.360

Cite this article as: Bak JG, Kim J, Ohk SH. Preparation of Tuna Skin Byproduct Film Containing Pinus thunbergii Cone Extract. Biomedical Science Letters. 2020. 26: 360-367. 